DOI 10.37882/2223-2974.2020.12.11

\title{
ПРОБЛЕМНЫЕ АСПЕКТЫ ВКЛЮЧЕНИЯ ТРЕБОВАНИЙ КРЕДИТОРА В РЕЕСТР ТРЕБОВАНИЙ КРЕДИТОРОВ ДОЛЖНИКА ПРИ ПРОЦЕДУРЕ БАНКРОТСТВА
}

\section{PROBLEMATIC ASPECTS OF INCLUDING THE CREDITOR'S CLAIMS IN THE REGISTER OF CREDITORS' CLAIMS OF THE DEBTOR IN BANKRUPTCY PROCEEDINGS \\ A. Gudkov \\ A. Krasilschikov V. Mishchenko}

Summary: The article examines a number of problems associated with the bankruptcy procedure. In particular, the problematic aspects of including the creditor's claims in the register of the debtor's creditors are highlighted. Analyzing the legislation and judicial practice regarding the presentation by the creditor of claims to the debtor in bankruptcy, the authors offer their vision of resolving problematic aspects.

Keywords: bankruptcy, debtor, creditor, register of claims, bankruptcy estate, contesting the transaction.

\author{
Гудков Анатолий Иванович \\ К.ю.н., дочент, ВЮИ ФСИН России \\ gudkovaniv@yandex.ru \\ Красильщиков Анатолий Владимирович \\ К.ю.н., дочент, ВЮИ ФСИН России \\ krasilschikov@inbox.ru \\ Мищенко Вячеслав Иванович \\ К.ф.н., дочент, ВЮИ ФСИН России \\ vyacheslav-mischenko@mail.ru
}

Аннотация: В статье исследован ряд проблем, связанных с процедурой банкротства. В частности, освещены проблемные моменты включения требований кредитора в реестр требований кредиторов должника. Проводя анализ законодательства и судебной практики в части предъявления кредитором требований должнику при банкротстве, авторы предлагают свое видение в разрешении проблемных аспектов.

Ключевые слова: банкротство, должник, кредитор, реестр требований, конкурсная масса, оспаривание сделки.
$\Pi$ роцедура банкротства предусматривает включение в реестр требований должника любых кредиторов, имеющих имущественные претензии к должнику. Однако, как показывает практика арбитражных судов и Верховного Суда Российской Федерации, кредитору все сложнее приходится обосновывать свои требования, а доказыванию теперь подлежат определенные факты, наличие которых обязан проверить арбитражный суд.

В частности, обоснованиями требований кредитора являются невыполненные денежные обязательства должника: просроченный кредит или не вовремя возвращенный заем с процентами, отсутствие оплаты по договору купли-продажи или поставки, отсутствие расчетов по договору подряда, аренды, а также неисполненные судебные акты, вступившие в законную силу.

Однако, кроме документов, подтверждающих наличие задолженности, предоставленных суду, кредитор должен доказать факт предоставления работ (товаров, услуг) или происхождение заемных средств по предъявленным им требованиям. Стоит отметить, что все договора или судебные акты, вступившие в силу в течение 3-х лет до подачи заявления о банкротстве, могут быть оспорены как финансовым управляющим, так и иными кредиторами в деле о банкротстве. Фактически, сомне- нию подвергается любая сделка кредитора и должника, но обязанность доказывания имущественных требований возлагается именно на кредитора.

Возможность нового оспаривания вступивших в силу судебных актов создает правовой прецедент, при котором решение, подлежавшее ранее несомненному исполнению в исполнительных органах ФССП, подлежит новому переосмысливанию арбитражным судом первой инстанции. Для судьи арбитражного суда первой инстанции, рассматривающего заявление кредитора о его включении в реестр, предъявленный им судебный акт в качестве обоснований его требований, не имеет заранее установленной юридической силы, и судья обязан заново исследовать все обстоятельства по делу, проверяя легитимность спора и учитывая новые доводы или возражения других кредиторов.

Подобное обстоятельство меняет иерархичную сущность судебной системы, когда решения судов первой инстанции общей юрисдикции могут быть оспорены только в установленный законом срок и только в определенной последовательности: апелляционной, кассационной. В деле о банкротстве вступившее в силу решение суда по гражданскому делу или мировое соглашение, утвержденное судом, снова пересматриваются арбитражным судом первой инстанции. Фактически, 
вступившее в силу решение суда по гражданскому делу, подвергается сомнению и подлежит повторной переоценке арбитражным судом.

Позиция многих юристов и адвокатов неоднозначна в вопросе справедливости такого подхода. Однако, судебная коллегия по гражданским судам Верховного Суда Российской Федерации поставила окончательную точку в этом вопросе, обобщив судебную арбитражную практику по вопросам банкротства и представив собственные судебные акты суда высшей инстанции, которые стали обязательными в правоприменительной практике иных судов [3,5,6,7].

В частности, В определении ВС РФ от 24.12.2015 года (дело № 304-ЭС15-12643) сам факт обжалования судебных актов, вступивших в силу, назван экстраординарным, так как в процессе банкротства арбитражными судами осуществляется пересмотр решений по ошибочно взысканным средствам с должника [4]. При этом суд указывает, что право оспаривания предоставлено лицам, которые не участвовали ранее в деле, и так как права кредиторов затрагиваются вступившим в силу судебным актом, он может быть пересмотрен с учетом мнения кредиторов должника.

Субъектами обжалования вступивших в силу судебных актов становятся конкурсные кредиторы и финансовый управляющий. При этом ни должник, ни кредитор, предъявивший к исполнению данный судебный акт, не праве оспаривать его в судебном порядке, так как они являлись непосредственными участниками спора и исчерпали данные возможности. В свою очередь, кредиторы могут реализовать право лиц, которые не участвовали в рассмотрении оспариваемого судебного акта, но получили право на защиту своих интересов, так как применяемый кредитором судебный акт непосредственно затрагивает их права на формирование справедливого объема конкурсной массы.

В свою очередь, заявление конкурсного кредитора приравнено по своей сущности к исковому заявлению лица. Поэтому основания его кредиторских требований подлежат тщательному анализу, а предъявленные им судебные акты в качестве оснований не имеют заранее установленной силы для арбитражного суда, даже если судебный акт вступил в силу.

В данном ключе суд применил такую практику по банкротству, при которой исковые требования могут быть повторно рассмотрены в суде в другом процессе, но не подлежат повторному рассмотрению в ином деле о банкротстве. Следовательно, отказываясь от претензий в банкротстве, кредитор утрачивает право истца на подачу иска, если дело о банкротстве будет прекращено. Данные обстоятельства следует учитывать кредиторам, которые выразили намерения заключить мировое соглашение.

Кроме того, заявляя об оспаривании судебного акта в рамках дела о банкротстве, кредиторы, вследствие схожести процедуры, нередко требуют пересмотреть судебный акт по вновь открывшимся обстоятельствам в порядке главы 37 АПК РФ. Здесь нужно учитывать, что в процедуре банкротства данное требование в таком порядке не рассматривается.

В целом, иски об отмене судебных актов в рамках процедуры банкротства подаются кредитором в порядке, предусмотренном постановлением Пленума ВАС РФ от 22.06.2012 г. № 35 [8]. В материалах названного Пленума содержится понятие «экстраординарного» обжалования ошибочного взыскания. Несмотря на схожие моменты с процедурой пересмотра дел по вновь открывшимся обстоятельствам, предусматривающей прежде всего подачу новых доказательств в деле, установление дополнительных обстоятельств по делу, отмена судебного акта лицами, участвовавшими ранее в деле, оспаривание сделок или решений судов в деле о банкротстве осуществляется новыми лицами.

В данном случае отсутствуют новые обстоятельства, послужившие причиной пересмотра дела. В частности, рассматривается право кредитора на оспаривание утвержденного судебного акта в интересах остальных кредиторов, которые заинтересованы в сохранении конкурсной массы должника и оспаривают требования других участников банкротства, основанных, по их мнению, на ошибочных доказательствах или вынесенных судебных актах.

При этом правом на обжалование вступившего в законную силу судебного акта обладает, кроме конкурсного управляющего, кредитор, заявивший о своих требованиях к должнику. Если заявление кредитора принято к рассмотрению арбитражным судом, он получает законные полноценные права наравне с другими участниками, даже если его требования оспариваются, и он не включен в реестр. В частности, при оспаривании судебных актов суд обязан проверить обоснованность судебного акта, так как признание судебного решения в качестве доказательства повлияет на объем конкурсной массы и на права иных кредиторов.

Основаниями для оспаривания сделок в процессе банкротства также являются подозрительные сделки должника. Некоторые кредиторы предъявляют требования к должнику, будучи аффилированными с ним лицами. Например, кредитор является руководителем исполнительного органа должника. Однако, сами по себе признаки аффилированности не доказывают мнимость сделок и не приводят к их недействительности, если суд 
не установит факт отсутствия самой сделки или надлежащих доказательств по ее заключению.

В Обзоре судебной практики ВС РФ от 29.01.2020 г. определен единообразный подход к вопросу правомерности включения кредитора в реестр требований кредиторов должника в процессе банкротства [5].

В частности, обязанность доказывания факта отсутствия аффилированности возложена на заявившего кредитора, который, в свою очередь, должен доказать наличие правоотношений с должником по сделке и ее экономическую целесообразность. Так, если сделка не имела экономической выгоды для кредитора, она не несет юридических последствий для сторон и может быть признана судом ничтожной. Верховный Суд указывает на необходимость глубокого анализа взаимоотношений должника и заявившего кредитора, обращая внимание на то, что надлежаще собранный пакет доказательств о наличии сделки мог быть предоставлен аффилированным лицом для убедительности, поэтому судам необходимо устанавливать факт реальности взаимоотношений сторон по сделке, исходя из первичной документации и отчетности.

Верховный Суд подчеркивает, что сделка не должна быть для кредитора экономически неразумной. Например, если в результате такой сделки кредитор сам приобрел признаки банкротства либо совершал иные действия, которые ему были невыгодны, исходя из экономических соображений, в частности, если кредитор предоставлял должнику денежный заем, заведомо понимая о невозможности его возврата в силу неплатежеспособности должника.

Верховный Суд отмечает, что, будучи аффилированными лицами, кредитор и должник с целью общих интересов заключают мнимые сделки в ущерб иным кредиторам в деле о банкротстве. При этом в качестве доказательств сделки они предоставляют полный пакет документов, что дает право суду усомниться в реальности сделки, и поэтому необходимо изучить иные доказательства в деле. Недостаточно исследовать платежные поручения по денежным проводкам, необходимо проанализировать бухгалтерскую документацию обеих сторон, проверить налоговую отчетность.

В Постановлении Пленума ВАС РФ от 30.04.2009 г.
№ 32 указывается недопустимости злоупотребления должником своими правами в ущерб интересам иных кредиторов, в связи с чем у кредитора или финансового управляющего возникает право на оспаривание сомнительной сделки должника, в том числе заключенной с одним из утвержденных кредиторов, если в результате этой сделки уменьшилась конкурсная масса [2]. При этом срок исковой давности по оспариванию таких сделок должника начинает течь со дня, когда конкурсный кредитор узнал о наличии подозрительной сделки.

В частности, Постановление Пленума ВАС № 32 в качестве основания для оспаривания указывает сделки, по которым произошло отчуждение имущества, выплачены отступные, произведен зачет требований или же подписано мировое соглашение [2].

В свою очередь, статья 206 Закона о банкротстве позволяет в порядке признания ничтожности оспорить подозрительные сделки должника, которые заключены за один год до его банкротства [1]. При этом законодатель связывает подозрительные сделки исключительно с уменьшением конкурсной массы (имущества должника) в процедуре банкротства. Поэтому кредиторам, обратившимся с требованием в процессе банкротства, необходимо предоставить доказательства реальности взаимоотношений сторон по сделке. Таким доказательством может служить переписка с должником, письменные претензии и ответы на них. При этом стоит отметить неодинаковый подход арбитражного суда в момент критического оценивания доказательств в деле о банкротстве. Если в обычном судебном порядке истцу необходимо предоставить в арбитраж договор, акты выполненных работ и акты сверок, транспортные и иные накладные, расписки, и этих доказательств достаточно, чтобы в бесспорном порядке взыскать долг, то в процессе банкротства, при наличии признаков аффилированности сторон, сам по себе надлежащий пакет документов, подтверждающий наличие задолженности, является оспоримым и подлежит переоценке с позиции экономической целесообразности сделки и проверке отчетности кредитора и должника, которая подтверждает кредиторскую задолженность. Такой тщательный анализ вызван необходимостью защиты прав других кредиторов в процессе банкротства, поэтому часто позиция Верховного Суда РФ не совпадает с правовыми позициями арбитражных окружных и апелляционных судов.

\section{ЛИТЕРАТУРА}

1. Федеральный закон «0 несостоятельности (банкротстве)» от 26.10.2002 N 127-Ф3 (последняя редакция) // http://www.consultant.ru/document/cons_ doc_LAW_39331.

2. Постановление Пленума Высшего Арбитражного Суда РФ от 30 апреля 2009 г. N 32 «0 некоторых вопросах, связанных с оспариванием сделок по основа- 
ниям, предусмотренным Федеральным законом «0 несостоятельности (банкротстве)» (с изменениями и дополнениями) // URL: cистема ГAPAHT: http:// base.garant.ru/1791083/\#ixzz6drrhy9z3

3. Обзор судебной практики Верховного Суда Российской Федерации, утвержденный Президиумом Верховного Суда Российской Федерации 27 ноября 2019 г. № 3 (2019) // http://www.supcourt.ru/documents/practice/28477.

4. Определение Судебной коллегии по экономическим спорам Верховного Суда РФ от 24.12.2015 N 304-ЭС15-12643 по делу N A45-6961/2014 // https:// legalacts.ru/sud/opredelenie-verkhovnogo-suda-rf-ot-24122015-n-304-es15-12643-po-delu-n-a45-69612014/

5. Обзор судебной практики разрешения споров, связанных с установлением в процедурах банкротства требований, контролирующих должника и аффилированных с ним лиц, утвержденный Президиумом Верховного Суда Российской Федерации 29 января 2020 г. // http://www.garant.ru/hotlaw/ federal/1316699/

6. Обзор судебной практики Верховного Суда Российской Федерации № 2 (2020), утвержденный Президиумом Верховного Суда Российской Федерации 22 июля 2020 г.// http://www.consultant.ru/document/cons_doc_LAW_358150/

7. Обзор судебной практики Верховного Суда Российской Федерации № 1 (2020), утвержденный Президиумом Верховного Суда Российской Федерации 10 июня 2020 г. // http://base.garant.ru/74242552

8. Постановление Пленума ВАС РФ от 22.06.2012 N 35 (ред. от 21.12.2017) «0 некоторых процессуальных вопросах, связанных, с рассмотрением дел 0 банкротстве»// http://base.garant.ru/70203722/

○ Гудков Анатолий Иванович (gudkovaniv@уandex.ru), Красильщиков Анатолий Владимирович (krasilschikov@inbox.ru), Мищенко Вячеслав Иванович (vyacheslav-mischenko@mail.ru).

Журнал «Современная наука: актуальные проблемы теории и практики»

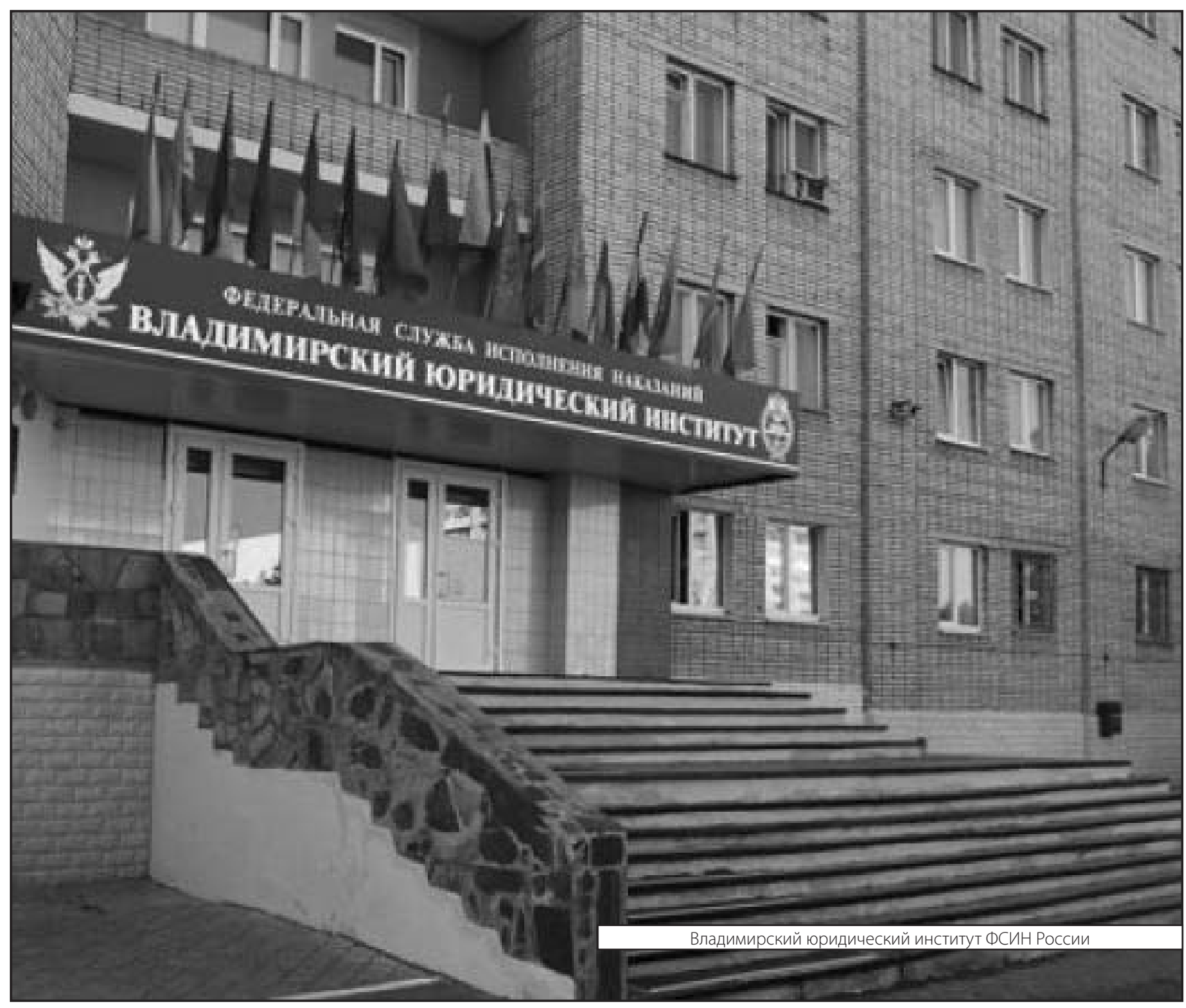

